\title{
有害業務を含む中小企業従業員の栄養拱取 量と血液性状，体位等との関係について
}

(昭 和 39 年 2 月 1 日 受 理)

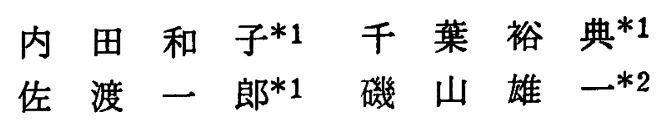

Studies on the Relation between Nutrient Intake and Blood Data and Physical Conditions of Workers in Medium and Small Enterprises

Kazuko UCHIDA*1, Hirosuke CHIBA*1, Ichiro SADO*1, and Yuichi ISOYAMA*2

(*1 Department of Public Health, School of Medicine, Juntendo University: Hongo, Bunkyo-ku, Tokyo; ${ }^{* 2}$ Colleen Pencil Company: Odai, Adachi-ku, Tokyo)

The authors have analysed the correlation between the dietary intake of nutrition and hematocrit, hemoglobin, erythrocytes, specific gravity of blood, physical and economic status. Studies were carried out on the total number of 72 men and women who work in medium and small enterprises in Tokyo.

The results were as follows:

1. The dietary intake of calories, vitamin $A$, vitamin $B_{2}$, calcium and iron were deficient about $20 \sim 55 \%$ compared with the amount of their nutritional requirements.

2. Body height, weight and weight-height ratio were lower than the average of in this country in males and females.

3. There were no correration between the animal protein intake and weight-hight ratio.

4. The coeficient correlation between the animal protein intake per day and hemoglobin and hematocrit values in blood were $r=0.367 \quad r=0.343$ in males, these were significant at the 0.05 level.

5. The coeficient of correlation between the animal protein intake per day and the income per month were $r=0.417$ in males, $r=0.341$ in females, these were significant at the 0.05 level.

(Received February 1, 1964)

\section{I 緒 言}

有害業務を含む中小企業従業員の健康管理方式につい て, 教室の松田 ${ }^{11}$ は，一中小企業に働く従業員の健康に ついて，人側および環境側と両面よりの実態調査を行な い，若干の知見を得たが，それによるとこのような職場 に働く従業員のなかには, 筫血乃至貧血傾向を示す者が 多くみられ，血中へモグロビン量よりかれらの摄取栄養

$*_{1}$ 順天堂大学医学部公衆衛生学教室: 東京都文京区 本郷 1-1

*: コーリン鉛筆株式会社総務部：東京都足立区小台 6850
量をみると，とくに総熱量，タンパク質，脂肪，鉄の四 栄養素において，へモグロビン值の低い群ほど、これら の摂取量が少ない傾向が認められたとのべている.

著者らは栄養調查をさらに詳細に行ない, これと血夜 性状, 体格, 尿所見, 経済状態, 自覚症など, 多角的に 検討し,これら中小企業従業員健康管理の重点について 考察を試みた。

\section{II 対象およひ方法}

対象は都内某工場従業員男女約 250 名中より，無作為 に男女おのおの 36 名，合計72名を抽出した．平均年令は 男子 27 才, 女子 25 才, 平均勤続年数男子 6 年, 女子 4 年 
で，男女とも $80 \%$ が現場系であった．検査は昭和 35 年 5 〜 6月で，つぎのような項目について調查を行なった.

\section{1. 栄養調查}

食事記録表 7 枚を 1 組とし，各自が毎日摄取した献立 内容および量を, 間食も含めて逐一明細に，1週間にわ たり記録させた.これをもとに食品群別重量に換算し， 食品類別荷重平均成分表 ${ }^{2)}$ を用いて，1 1 日当り栄養 摄取量を算出した。

\section{2. 身体計測}

身長は木製の台付身長計，体重は検定済自動式科を用 いた.

\section{3. 血液検查}

採血は肘静脈より約 $3 \mathrm{ml}$, 乾燥堿菌注射简にて行な い, 直ちに硫酸銅法")により全血比重(以下 GB と略す) を測定し，残りの血液 $1 \mathrm{ml}$ 当り $2 \mathrm{mg}$ の二重シュウ酸 を加えて凝固阻止したのちウイントローブ管に入れ， 1 分間 3000 回転30分間遠心沈殿を行なって，へマトクリッ 卜值 (以下 Ht と略す)を測定した。へモグロビン值 (以 下 $\mathrm{Hb}$ と略す）は，ザーリーピペットで血夜を $0.01 \mathrm{ml}$ とり， $0.1 \mathrm{~N}$ 塩酸で 750 倍希积とし，日立製光電光度計
を用い, 光電比色法4により測定し $\mathrm{g} / \mathrm{dl}$ 值に換算した。 赤血球数 (以下 Rote と略す) は, 血液 $0.01 \mathrm{ml}$ を八イ エム氏液で 400 倍希釈し，ビュルケルチュルク計算板を 用いて計測しだ).

\section{4. 尿検査}

新鮮尿について，糖はテステープ，タンパクは $20 \%$ ス ルホサリチル酸6)，ウロビリノーゲンはエールリッヒ氏 アルデヒド反応们により検査した.

\section{5. 質問紙による調査}

消化器疾患調查表 ${ }^{7)}$, 健康調査表 (C. M. I. $)^{892)}$ を自己 記入させ, 月収については会社の会計課において直接調 查し，さらにこれとは別に家庭の月収と 1 か月平均小づ かい額を記入してもらった。

\section{III 調查成紩}

\section{1. 栄養調查成績}

第 1 表に示すように，軽労作所要量に比べて，力ロリ 一は男子76\%，女子 $80 \%$ ，カルシウムは男子70\%，女子 $80 \%$ ，鉄は男女とも $60 \%$ ，ビタミンAは男子 $45 \%$ ，女子 $65 \%$ ，ビタミン $\mathrm{B}_{2}$ は男子 $57 \%$ ，女子 $72 \%$ しか摂取されて おらず，いずれも低栄着の傾向が認められた。

\section{第 1 表 摂 取 栄 養 (1人 1 日当り)}

\begin{tabular}{|c|c|c|c|c|c|c|c|c|c|c|c|c|c|}
\hline & & \multirow{2}{*}{ 熱 } & \multicolumn{3}{|c|}{ タンパク質 (g) } & \multirow{2}{*}{$\begin{array}{l}\text { 脂肪 } \\
(\mathrm{g})\end{array}$} & \multirow{2}{*}{$\begin{array}{l}\text { 糖質 } \\
(\mathrm{g})\end{array}$} & \multicolumn{2}{|c|}{ 無機質 (mg) } & \multicolumn{2}{|c|}{ ビ タ } & \multicolumn{2}{|c|}{$\Xi \quad y$} \\
\hline & & & 総量 & 動蛋 & 植蛋 & & & $\mathrm{Ca}$ & $\mathrm{Fe}$ & $\begin{array}{c}\text { A } \\
\text { I.U. }\end{array}$ & $\begin{array}{c}\mathrm{B}_{1} \\
\mathrm{mg}\end{array}$ & $\begin{array}{c}\mathrm{B}_{2} \\
\mathrm{mg}\end{array}$ & $\underset{\mathrm{mg}}{\mathrm{C}}$ \\
\hline $\begin{array}{c}\text { 男 子 } \\
\text { (36名) }\end{array}$ & $\begin{array}{l}\text { 平均值 } \\
95 \% \text { 信頼限界 }\end{array}$ & $\begin{array}{r}1905 \\
\pm 110\end{array}$ & $\begin{array}{r}68.8 \\
\pm 5.0\end{array}$ & $\begin{array}{r}27.6 \\
\pm 4.1\end{array}$ & $\begin{array}{r}41.5 \\
\pm 2.4\end{array}$ & $\begin{array}{r}34.7 \\
\pm 3.9\end{array}$ & $\begin{array}{r}327.7 \\
\pm 17.3\end{array}$ & $\begin{array}{r}425 \\
\pm 52\end{array}$ & $\begin{array}{r}15 \\
\pm 2\end{array}$ & $\begin{array}{r}909 \\
\pm 243\end{array}$ & \begin{tabular}{|r|}
1.15 \\
\pm 0.09 \\
\end{tabular} & \begin{tabular}{|r|}
0.75 \\
\pm 0.08 \\
\end{tabular} & \pm 17 \\
\hline $\begin{array}{l}\text { 女 子 } \\
\text { (36名) }\end{array}$ & $\begin{array}{l}\text { 平 均 值 } \\
95 \% \text { 信頼限界 }\end{array}$ & $\begin{array}{l}1733 \\
\pm 95\end{array}$ & $\begin{array}{r}64.5 \\
\pm 4.4\end{array}$ & $\begin{array}{r}26.0 \\
\pm 2.8\end{array}$ & $\begin{array}{r}38.6 \\
\pm 3.3\end{array}$ & $\begin{array}{r}34.0 \\
\pm 2.9\end{array}$ & \pm 17.0 & $\begin{array}{r}477 \\
\pm 49\end{array}$ & $\begin{array}{r}16 \\
\pm 2\end{array}$ & $\begin{array}{r}1305 \\
\pm 246\end{array}$ & $\mid \begin{array}{r}1.08 \\
\pm 0.08\end{array}$ & $\begin{array}{r}0.80 \\
\pm 0.08\end{array}$ & \\
\hline $\begin{array}{l}\text { 軽労 作 } \\
\text { 所 要量 }\end{array}$ & $\begin{array}{l}\text { 男 } \\
\text { 女 }\end{array}$ & $\begin{array}{l}2500 \\
2100\end{array}$ & $\begin{array}{l}70 \\
60\end{array}$ & & & & & $\begin{array}{l}600 \\
600\end{array}$ & $\begin{array}{l}10 \\
10\end{array}$ & $\begin{array}{l}2000 \\
2000\end{array}$ & $\begin{array}{l}1.3 \\
1.1\end{array}$ & $\begin{array}{l}1.3 \\
1.1\end{array}$ & 65 \\
\hline
\end{tabular}

\section{2. 体 格}

第 2 表に示すよろに，国民栄養調查時（昭和35年）に おける全国平均と比べ，女子の身長を除いてはいずれも 低い傾向にある。

\section{3. 血液検査成績}

第 3 表に示すように，男女とも Ht を除いて， GB， $\mathrm{Hb}$, Rote のいずれもが，正常範囲の下限近くか，それ 以下にあり，顊血乃至貧血傾向者の多い集団であるよう に思われる.

\section{4. 尿検查成績}

第 4 表では，ウロビリノーゲン陽性者率，男子 $37 \%$, 女子 $21 \%$ で，著者らが某夜間定時制高校と某宗教大学で 行なった結果の陽性率は，前者では $11.7 \%$ ，後者では $15.2 \%$ ，これに比べその出現率が若干多いように考え
られる。

第 2 表 身長と体重の全国平均との比較

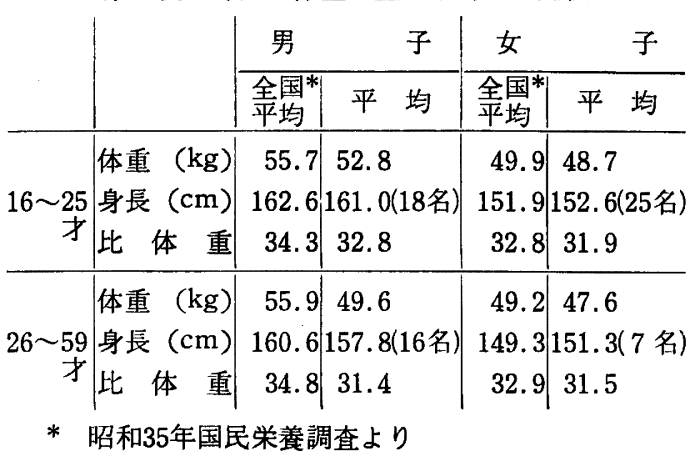




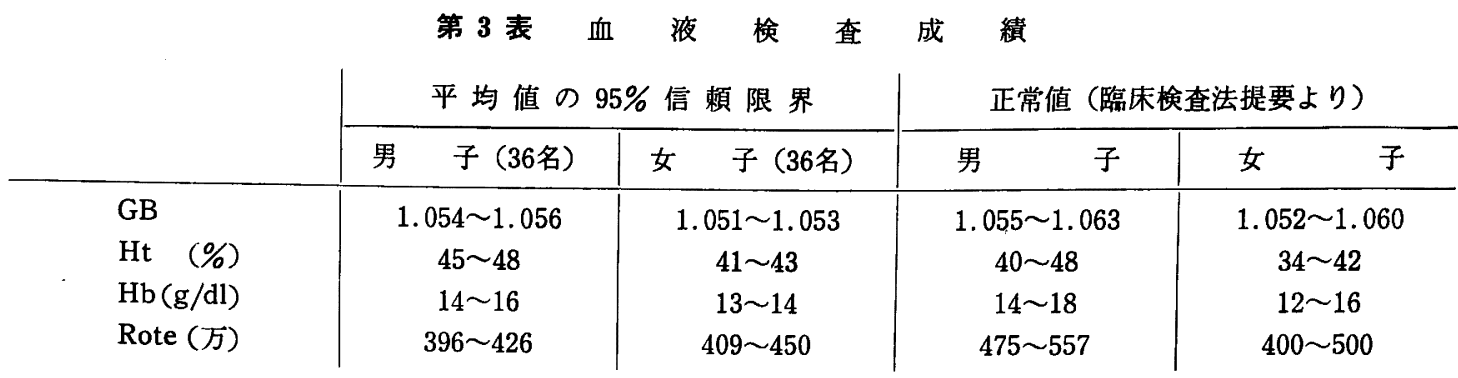

第 4 表 尿 検 查 成 績

\begin{tabular}{|c|c|c|c|c|c|c|}
\hline & & & $\begin{array}{r}\text { 男 } \\
\text { 人数 }\end{array}$ & 子 & $\begin{array}{r}\text { 女 } \\
\text { 人数 }\end{array}$ & $\begin{array}{l}\text { 子 } \\
\%\end{array}$ \\
\hline \multirow{2}{*}{ 尿 } & \multirow{2}{*}{ 糖 } & - & 35 & 100 & 32 & 97 \\
\hline & & + & 0 & 0 & 1 & 3 \\
\hline \multirow{2}{*}{\multicolumn{2}{|c|}{ 尿タンパク }} & - & 34 & 97 & 28 & 85 \\
\hline & & + & 1 & 3 & 5 & 15 \\
\hline \multirow{2}{*}{\multicolumn{2}{|c|}{$\begin{array}{l}\text { 尿ウロビリ } \\
\text { ノーゲン }\end{array}$}} & - & 22 & 63 & 26 & 79 \\
\hline & & + & 13 & 37 & 7 & 21 \\
\hline
\end{tabular}

\section{5. 栄養揸取量と比体重との関係}

第 5 表のように，栄養㨟取量と比体重の関係について みると, 太っている人が栄養摄取量が多いとのみはいえ ず，逆に第 6 表のように太っている人は，体重 $1 \mathrm{~kg}$ 当 りの摂取量が少ないという結果が示され，この傾向は男 子ょりも女子に強く，したがって太っている女性ではか なり食物の量を減らす努力をしているのではないかと考 えられた．男子では太っている人もそうでない人も食物 の量はあまり変らず, したがって太っている人は体重 1 $\mathrm{kg}$ 当り摂取量に換算した場合，当然摂取量が若干少な いという結果になる。

6. 栄養摂取量と血液性状との関俰

第 7 表のように, 栄養摂取量と血液性状との間には男
第 5 表 栄養摂取量と比体重との相関係数

\begin{tabular}{|c|c|c|c|}
\hline & & F (34名) & 女子 (32名) \\
\hline \multicolumn{2}{|c|}{ Cal } & 0.152 & -0.058 \\
\hline 動 & 蛋 & 0.053 & -0.140 \\
\hline 総 & 蛋 & 0.070 & -0.193 \\
\hline
\end{tabular}

第 6 表 体重 $1 \mathrm{~kg}$ 当り栄養摂取量と比体重 との相関係数

\begin{tabular}{ccc} 
& 男子 (34名) & 女子 (32名) \\
\hline $\mathrm{Cal} / \mathrm{kg}$ & $-0.371^{*}$ & $-0.686^{* *}$ \\
動蛋 $/ \mathrm{kg}$ & -0.274 & $-0.535^{* *}$ \\
総蛋 $/ \mathrm{kg}$ & $-0.409^{*}$ & $-0.620^{* *}$ \\
$* \mathrm{P}<0.05$ & & \\
$* * \quad \mathrm{P}<0.01$ & &
\end{tabular}

子は GB とカロリー, $\mathrm{Ht}$ と動蛋, $\mathrm{Hb}$ と動蛋, 女子で は GB と動蛋おのおのの間に有意の順相関が認められ た.この他には，女子のみに $\mathrm{GB}$ と脂肪摂取量との間 に $\mathrm{r}=0.421$ で有意の順相関がみられたが，糖質，無機 質,ビタミン類と血液性状との間には, 有意の関係は認 められなかったままた，体重 $1 \mathrm{~kg}$ 当り栄盖摂取量に関 しては，女子のみに $\mathrm{GB}$ と動蛋との間に $\mathrm{r}=0.353$ で有 意の順相関がみられたが，それ以外のものではとくに関 係は認められなかった。

第 7 表 栄養摂取量と血液性状との相関係数

\begin{tabular}{lccccccc} 
& \multicolumn{2}{c}{ 男 } & \multicolumn{2}{c}{$(36$ 名 } & \multicolumn{2}{c}{ 女 } & \multicolumn{2}{c}{ (36名) } \\
& $\mathrm{Cal}$ & 動 蛋 & 総 蛋 & Cal & 動 蛋 & 総 蛋 \\
\hline $\mathrm{GB}$ & $0.343^{*}$ & 0.248 & 0.303 & 0.254 & $0.354^{*}$ & 0.098 \\
$\mathrm{Ht}$ & 0.175 & $0.343^{*}$ & 0.277 & 0.221 & 0.170 & 0.014 \\
$\mathrm{Hb}$ & 0.292 & $0.367^{*}$ & 0.302 & 0.178 & 0.178 & 0.011 \\
$\mathrm{Rote}$ & -0.046 & 0.245 & 0.041 & 0.014 & -0.102 & 0.030 \\
$* \mathrm{P}<0.05$ & & & & & &
\end{tabular}

7. 栄養揸取量と経済状態との関係

動蛋摂取量と月収との間には, 男女とも有意の順相関
があったが，小つかかい類とはとくに関係がみられなかっ た(第 8 表). 月収は男子平均 15,000 円，女子平均 10,000 
円で，小づかい額は男女とも70\%が，月1,000円〜3,000 円であった。ちなみに総理府統計局資料による，昭和 35 年の都市勤労者世帯主の月収は, 5 階級に分けた最下級
で，12，372円であり，この最下級に近い収入の集団であ った.

第 8 表 栄着椇取量と経済状態との相関係数

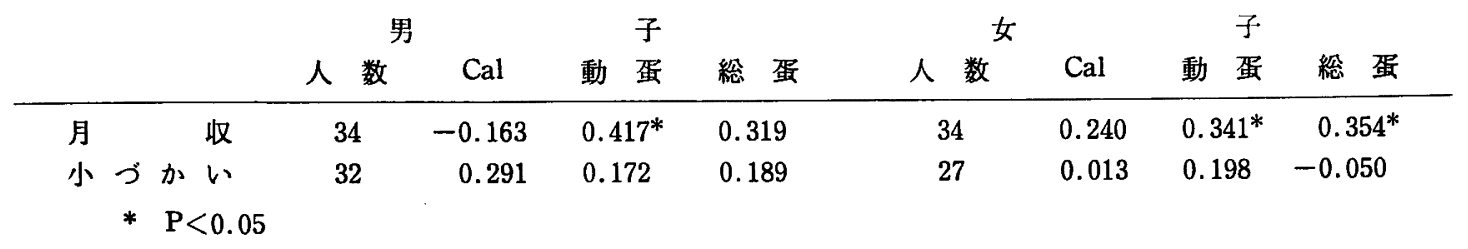

\section{8. 栄盖掑取量と尿所見, 自覚症との関係}

尿タンパク，尿ウロピリノーゲン陽性者と陰性者とで 栄盖摂取量に有意差はなかった。

消化器疾患調査表の 26 項目の質問から，第 1 四のよ3 な 7 つの訴えについて，男女別に割合をみたが，男女と も胃の調子がわるいという訴えと，女子に腹痛，便秘の 多いのが目立った．訴えのなかった者と訴えた者との間 に栄養摄取量の有意差はなかった。

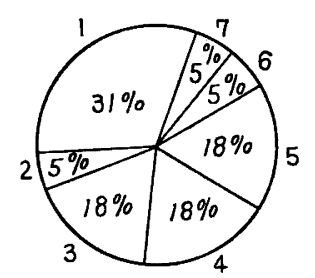

男子

訴え有する者 $40 \%$

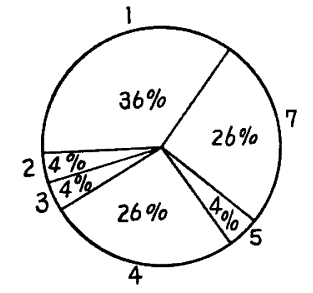

女子
1. 最近胃の調子が悪い
2. 最近ときどき吐く
3. みず拈ちが痛む
4. 腹が痛む

第 1 図 消化器症状訴え内容の割合

C.M.I.については, 深町10)の神経症判別図を用いて 4 領域に分けて，前記の訴えを持つ者の割合をみたとこ ろ, 領域 IからIVに進むにつれ, 消化器症状を有する者 の割合が増加する傾向にあった（第 2 図).
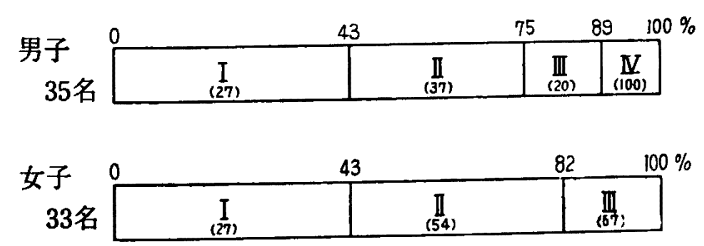

注） I IV C.M.I. 領域

（）数字は消化器症状訴え有する者の割合(\%)

第 2 图 C.M.I. 領域別消化器症状を有する者の割合

9. 血液性状と比体重, 経済状態との関係

男子の $\mathrm{Hb}$ と比体重との間に，いく分関係があるよ ろに思われるが (第 9 表)，有意の相関とはいえなかっ た. 男子 Ht と月収との間には有意の相関があった（第 10 表). 比体重と月収との間には関係がみられなかった。

第 9 表 血液性状と比体重との相関俰数

\begin{tabular}{lrr} 
& 男子 (34名) & 女子 (32名) \\
\hline $\mathrm{GB}$ & 0.232 & -0.051 \\
$\mathrm{Ht}$ & 0.133 & -0.182 \\
$\mathrm{Hb}$ & 0.324 & 0.112 \\
Rote & 0.073 & -0.059
\end{tabular}

第 10 表 血液性状と月収との相関係数

\begin{tabular}{llr} 
& 男子 (35名) & 女子 (34名) \\
\hline $\mathrm{GB}$ & 0.068 & -0.016 \\
$\mathrm{Ht}$ & $0.333^{*}$ & 0.012 \\
$\mathrm{Hb}$ & 0.155 & -0.087 \\
Rote & 0.271 & -0.086
\end{tabular}

$* \mathrm{P}<0.05$

10. 血液性状と尿所見, 自覚定との関係

尿タンパク，尿ウロビリノーゲン陽性者と陰性者と比 べ血夜性状には差はなかった．消化器症状について訴え を持つ者とそうでない者と比較すると， GB, Ht, Hb の いずれも平均値が訴えを持つ者に低い傾向がみられた が，有意差といえなかった。

IV 考按

個人あるいは集団の栄養状態を判定するには，従来か らいろいろの方法が用いられてきた。 それらのおもなも のとして, 身体および体力計測, 身体症候観察, 血液, 尿の理化学的検査, 栄養摄取状況調査等がある. 昭和 20 年以来, 全国で毎年行なわれている国民栄養調查では, 栄養と健康状態との関係を明らかにするために, 栄養摄 取状況の他に, 体位, 血圧, 脈搏身体症候等の調查をあ わせて行なっている. 
昭和35年度国民栄養調査成績 ${ }^{111}$ をみると，栄養基準量 に対する摂取量の割合が $65 \%$ 以下のものとして，ビタミ ン $\mathrm{B}_{2}$, ビタミン $\mathrm{A}$, カルシウム等があげられており，こ れらはとくに日本人に不足しがちな栄荃素と考えられる が,この集団もその例にもれず, さきの成績の項でのべ たが, ビタミン $\mathrm{B}_{2}$, ビタミン $\mathrm{A}$, カルシウム, 鉄, カロ リーが軽労作所要量の $45 \sim 80 \%$ しか摂取されていない状

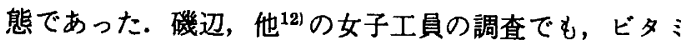
ソ $\mathrm{B}_{2}$ ，カルシウムがとくに所要量を下回っていた。

栄盖摂取量と体位に関しては，食糧不足は成長期には 身長の発育が著明に阻害され, 主婦, 老人では体重が低 下するとのべた佐藤ら ${ }^{13)}$ の報告の他に，吉村ら ${ }^{14)}$ の発育 期にある青少年について $1 \sim 2$ 名のの実験を行ない, 熱 量過剰群は対照群に比へてて，身長や筋力には差がなかっ たが，体重，胸团等の幅育は有意に増大したという報告 がある. 著者らの調查では, 栄養摂取量と比体重の間に は，相関係数の有意性は認められなかったが，この集団 の体位が全国平均に比べてむしろ少位にあること，血液 所見も正常值の下限近くかそれ以下であった事実などと 照し合わせて, 前記の栄盖摂取量の不足が，かれらの発 育の面に対して，なんらかの影響を及ほしているのでは ないかと考えられる.

栄荃と血液との関係に関する報告はかなり多い。平 出 ${ }^{16)}$ は実験的タンパク欠乏症において，Hb， GB，血清 アルブミン，血漿タンパクおよび GP の順に鋭敏な動き を示したので, 栄着欠乏症の指標として Hb が最適であ ると推奖した。 上田ら ${ }^{16)}$ は低タンパク，低カロリ一摂取 群は， Hb，血漿アルブミンがとくに鋭敏に減少すると のへ，磯辺 ${ }^{17)}$ は必須アミノ酸リシソ，スレオニン, トリ プトフフン, メチオニンについて, その摂取量の多いほ ど $\mathrm{Hb}$ が高く, タンパク $1.5 \mathrm{~g} / \mathrm{kg}$ 以上摂取者は, 1.1 $\mathrm{g} / \mathrm{kg}$ 以下の者に比べ， $\mathrm{Hb}$ が有意に高いとのべた. 諏 訪 $^{18)}$ は2,049人の調査から, 動蛋摂取量と GB との間に は $\mathrm{r}=0.32$ で有意の順相関がみられたと報告した．著者 らの結果では, 総タンパク摂取量と血液性状との間に は, とくに有意の相関はみられなかったが，動蛋摂取量 と $\mathrm{Hb}, \mathrm{Ht}$ との間には男子に有意の相関があり，女子 では動蛋と GBとの間に有意の相関がみられた. カロリ 一と GB との間には男子のみに有意の相関がみられた。 このように相関係数の有意性が男女間で一致しないが, 少なくとも総タンパクやカロリー摄取量よりも，動蛋摂 取量の方が血液性状と関係が深いように考えられる. そ してこの四項目の血液性状のうち，最も動蛋搨取量と関 係が深いのはどれかということになると， GB, Ht, Hb の三者については優劣をつけがたいが， Rote について は，測定法上最も誤差を生じやすいためからか，あるい は何か他の理由によるのか明らかではないが，関係がほ とんどみられなかった。

月収と動蛋摂取量との間には男女とも有意の関係がみ
られたが，経済要覧および FAO 資料191による世界27か 国の国民所得と動蛋摄取量も，第 3 図のように所得の多 い国ほど動蛋摂取量も多い、日本は27か国中23位という 情けない状態である．家庭においても食物の量や質が， 経済状態に左右され，それが体位血液性状にまでも影響 を及はすすことは，つぎにのべるような資料によっても明 らかである.

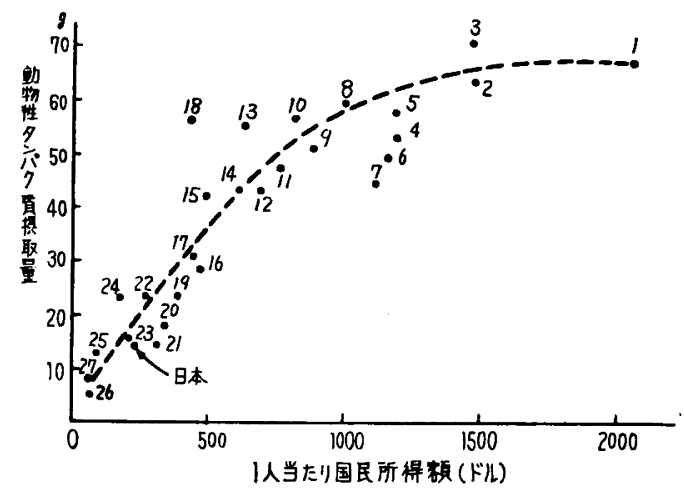

第 3 図 動物性タンパク質摂取量と国民所得との関係

佐藤ら ${ }^{201}$ は給料生活者の $\mathrm{Hb}$ は, 経済生活水準と密接

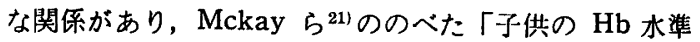
は一家の収入で動く」ということと照し合わせて興味あ る事実であると報告した。磯辺 ${ }^{22)}$ は女子大生に比較し て, 低所得噌女子は, タンパク摂取量には差はないが, 動蛋摂取量に差があり，一般にやせ型で血獎タンパクは 正常範囲にあったが， GB と $\mathrm{Hb}$ が低かったとのべてい る. 長嶺ら ${ }^{23)}$ は, 低所得層の栄養摂取量は全国平均に比 ベて, タンパク質, 動蛋比が低く，やせ型で Hbの低い 者が30〜60\%あったと報告した. 定時制高校生について も，収入が少なく，小つかかいの自由に使えない者に $\mathrm{Hb}$ の低いのが多かったという千葉 ${ }^{24)}$ の報告があり，家庭主 婦については里和25)の下階層は上階㬝に比べ, 貧血, 低 タンパク血症，低コレステロールの著が多かったという 報告がある.

今回の対象となった集団は，環境要因についての問題 解決の外に, 家庭経済的問題, なかんずく, 食生活の改 善について，さらに一層の努力がのぞまれるのである.

尿タンパク，尿ウロビリノーゲン有所見者は，栄養摂 取量や血液性状とは余り関係がないように思われる。し かしこのような 1 回だけの断面調查で有所見であるとい うことが，直ちに異常であると判定してしまうことはで きず，さらに詳細な追求が必要であると考えられる.

自覚症については, 消化器症状の訴えの多い者に神経 症的傾向が多いようにみうけられた。

$\mathrm{V}$ 結 論

著者らは，有害業務を含む都内中小企業従業員健康管 
理の一環として，男女72名について栄養摄取量と血液性 状, 体格, 経済状態などとの関係について検討したとこ ろ,つぎのような知見を得た.

1. 男女とも、ビタミン $\mathrm{A}$, ビタミン $\mathrm{B}_{2}$,カルシウム, 鉄, カロリー，撽取量が所要量に比べて20〜 $55 \%$ 不足し ていた。

2. 身長, 体重, 比体重は, 全国平均に比較して男女 とも低い傾向にあった.

3. 1 日当り栄養摂取量と比体重とは有意の関係がみ られなかった。

4. 男子において動蛋摄取量と血中へモグロビン, 人

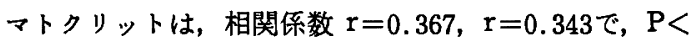
0.05 で有意の相関であった。

5. 1 日当り動蛋摂取量と月収とは, 相関係数男子 $r=0.417$, 女子 $r=0.341, P<0.05$ で有意の相関がみら れた.

稿を終るにあたり御指導, 御校閱下さった順天堂大学 医学部小谷新太郎教授に深く感謝の意を表わすとともに 研究に快く御協力いただいたコーリン鉛筆株式会社谷中 製造部長, 長谷川研究課長に厚く御礼申上げます.また 終始御協力下さった順天堂大学医学部公衆衛生学教室の 皆様に御礼申上げます。

文献

1）松田善雄 : 順天堂医学雑誌 7, 2 (1961).

2）香川昇造編 : “食品成分表” 栄養短大出版(1960).

3）吉川春寿 : “硫酸銅法” 学術書院 (1949).
4）斉滕正行 : “光電比色法による臨床化学検查” 南 山堂 (1953).

5）勝沼晴雄, 他編 : “職業病検診の手技” 日本加除 出版 (1956).

6）金井 泉: “臨床検查法提要” 金原出版 (1960).

7) 佐藤信一：労災 8, 3 (1954).

8）勝沼啨雄, 他編：“公衆衛生集団検診法”医蒾薬 出版 (1960).

9) K. Brodman, et al.: J.A.M.A. 140 (1949).

10) 深町 建 : 福岡医学雑誌 50 (1959).

11）厚生省編：“国民栄養の現状”第一出版 (1962).

12）磯辺しつ子，松沢九二雄：国立栄養研究所研究報 告 (1957).

13）佐藤徳郎, 他：医学と生物学 14, 1 (1949).

14）吉村寿人, 他：栄養と食糧 10, 3 (1957).

15）平出順吉郎：生体の科学 1(1950).

16）上田英雄, 他：日本内科学会誌 38, 2, 3(1949).

17）磯辺しつ子：栄湌学雑誌 19，1（1961）.

18）諏訪 栄: 生物統計学雑誌 8, 4 (1961).

19）資源調査会編：“日本の食糧”第一出版（1962）.

20）佐藤徳郎, 他：医学と生物学 13，3 (1948).

21) Mckay, et al.: Br. Med. J. 11 (1946).

22）磯辺しう’子：栄養学雑誌 19, 1 (1961).

23）長嶺晋吉, 他 : 国立栄隍研究所研究報告 (1961).

24）千葉裕典：民族衛生 24，3（1958）.

25）里和スミエ：日本公衆衛生雑誌 9, 1 (1962). 